Fecha de recepción: abril 2018

Fecha de aceptación: noviembre 2018

Versión final: diciembre 2020

\section{Design as an agent of change: Practice-oriented initiatives on Design Teaching}

Najla Mouchrek * and Lia Krucken ${ }^{\star *}$

\begin{abstract}
The paper analyzes the role of Design as an agent of social transformation in face of complex challenges. Intentionally embracing reality's complexity and centering on human values, the Design approach is suited to develop alternative perspectives and radically different strategies for change. The paper explores Design teaching focusing on social change and transition to sustainability, presenting three initiatives and reflecting about methods and impacts of the application of Design for transition. The analysis points to the need of a critical vision in Design research and teaching and the importance to systematize and teach methods and tools to support the interplay among diverse social actors.
\end{abstract}

Key words: Design Culture - Design for change - Social Change - Transition to Sustainability - Design Activism - Complexity - Wicked Problems.

[Abstracts in spanish and portuguese at pages 137-138]

${ }^{(* *)}$ Najla Mouchrek is a doctoral candidate in the Interdisciplinary $\mathrm{PhD}$ with focus on $\mathrm{Hu}$ man Centered Design at Virginia Tech. Established graphic design for the last two decades, Mouchrek developed a passion for applying design as an agent of change for youth development and engagement with sustainability and social change. She holds a Bachelor's Degree in Communication (Federal University of Minas Gerais, Brazil). In the course of her Master degree in Design, Innovation and Sustainability (State University of Minas Gerais, Brazil), she developed a model for youth engagement using design principles and practices. She also worked as a leading mentor in sustainable education for youth in several projects in Brazil. As a graduate assistant in the Office of Undergraduate Affairs at Virginia Tech, Mouchrek works supporting student-centered initiatives. She serves a co-chair for the university's strategic planning on experiential learning. In her PhD, Mouchrek is working on interdisciplinary research investigating design-based innovative learning strategies to promote youth empowerment and transformative developmental outcomes during the transition into adulthood.najlamk@vt.edu

${ }^{(*)}$ Lia Krucken works as a design educator and facilitator, and as a visual artist. She holds a PhD in Design at Federal University of Santa Catarina and Politecnico di Milano (2005), where she also has been collaborating occasionally as guest professor. She is international associated at Plataforma Design, a Brazilian non-governamental organization for design, culture and biodiversity. She also collaborates with Cocreando Srl that is an international research, strategy and design studio based in Milan, Italy. She has been working as a de- 
sign researcher and professor with institutions in Brazil, Germany and Italy for the last 15 years. Currently she lives in Berlin and researches creative processes in urban contexts. liakrucken@pq.cnpq.br

\section{Introduction: Design as a Culture of Inquiry and Action ${ }^{1}$}

This paper presents an analysis on the nature of Design as a culture and its role as an agent of social transformation in face of increasingly complex challenges. It starts by presenting a literature review on the origins and processes of development and recognition of Design as a distinctive culture of inquiry and action in the world.

The practice of Design is as ancient as human civilization. Design helped us to become who we are: it was the ability to design and create tools what determined our humanity and began the human culture (Friedman, 2000). Thus, Design was the first tradition of inquiry and action developed over time, being present in almost all aspects of the world we live in (Nelson \& Stolterman, 2003). Although an essential part of human traditions, the culture of Design remained surprisingly invisible and unrecognized as a particular way of knowing and acting in the world. This theme is largely explored by Friedman (2000), Cross (1982), Nelson \& Stolterman (2003).

Several authors consider Design as a third culture, a third mode of knowledge and understanding of reality, alongside the sciences and the humanities (Archer, 1979; Cross, 1982, 1999, 2006; Nelson \& Stolterman, 2003). While other traditions have long been recognized as dominant in our social, cultural and educational systems, the culture of Design has been neglected and not properly named or articulated. Thus, as pointed out by Cross (1982), this third culture is not easily recognizable as such. Supported by the work of Archer (1979), Cross (1982), proposes the model of three major areas of knowledge, comparing their phenomena of study, research methods and key values. Here is a summary in Table 1.

\begin{tabular}{|l|l|l|l|}
\hline & Phenomenon of study & Appropriate methods & \multicolumn{1}{|c|}{ Values } \\
\hline Sciences & The natural world & $\begin{array}{l}\text { Controlled experiment, } \\
\text { classification, analysis }\end{array}$ & $\begin{array}{l}\text { Objectivity, rationality, } \\
\text { neutrality, and a concern } \\
\text { for 'truth' }\end{array}$ \\
\hline Humanities & Human experience & $\begin{array}{l}\text { Analogy, metaphor, } \\
\text { criticism, evaluation }\end{array}$ & $\begin{array}{l}\text { Subjectivity, imagination, } \\
\text { commitment, and a } \\
\text { concern for 'justice' }\end{array}$ \\
\hline Design & The man-made world & $\begin{array}{l}\text { Modeling, pattern- } \\
\text { formation, synthesis }\end{array}$ & $\begin{array}{l}\text { Practicality, ingenuity, } \\
\text { empathy, and a concern } \\
\text { for 'appropriateness' }\end{array}$ \\
\hline
\end{tabular}

Table 1. Model of 'three cultures' view of human knowledge and ability. Source: Cross (1982). 
Design is a field of knowledge still in process of articulation and maturation, not presenting a long and well-developed academic history like other traditions, as suggested by Friedman (2000) and Cross (1999), among others. In the conception of Nelson \& Stolterman (2003), this is also due to the fact that, under the influence of polarization and separation between thought and action, typical of Western thinking tradition, the historical roots of the tradition of Design were discontinued. The authors analyze that during the Pre-Socratic Age, the definition of wisdom (sophia) was an integration in thought and action, reflection and production. At the time of Socrates, Plato and Aristotle, this notion was divided -sophia has become primarily the search for fundamental principles and ideas- taken as more important and superordinate; separated from the practical wisdom and productive action. The original understanding of Design then lost its strength, not evolving to be a tradition of research and action as did the Science and the Humanities, over time.

In this sense, one can identify the need and at the same time, the opportunity to resume the tradition of Design in its uniqueness and to reconstruct it as a coherent and strong field, based on past experience and also deeply connected to contemporary challenges and future visions.

Cross (1999) has identified since the 1990s a fundamental need for awakening to the force and intrinsic quality of Design Thinking, creating conditions for acceptance, recognition and articulation of Design as a discipline in its own way. The present paper aims to contribute to a reflection on the nature of Design, investigating its potential as an alternative mode of intervention to address and tackle complex social issues.

The focus of Design is evolving toward a systemic perspective, increasing its field of action. "The transition to a sustainable society will require new ways of designing that are informed by a vision, a deep understand of the dynamics of change and a new mindset and posture", as states Irwin (2015, p. 234).

In the next section, the paper investigates the role of Design in the face of contemporary challenges, laying out the unique and dynamic set of skills, cognitive processes and methods characteristic of Design, which makes it a promising agent in contexts of change and a powerful methodology for social intervention.

\section{The Role of Design in Face of Contemporary Challenges}

The current research and action traditions do not support meeting the emerging challenges in an increasingly complex and multifaceted reality, as Nelson \& Stolterman (2003) stand. Banerjee (2008) argues that the ways of understanding and acting in the reality from which we structure and conduct the world need to be fundamentally reestructured to address the critical nature of these challenges.

Most of the problems we deal with today, especially in the social sphere, are complex and require different methods of solution, compared to common problems. They are what Rittel (1973) called wicked problems. Following is an overview of these problems (Table 2), based on the work developed by Rittel (1973) and later synthesized by Nelson \& Stolterman (2003) and Savoy (2012). 


\begin{tabular}{|l|l|}
\hline Characteristics & Consequences \\
\hline $\begin{array}{l}\text { Problems are incomplete, } \\
\text { contradictory and include } \\
\text { changing requirements. }\end{array}$ & $\begin{array}{l}\text { Solutions for them are often difficult to recognize } \\
\text { because of their interdependence. }\end{array}$ \\
\hline $\begin{array}{l}\text { The nature of the problem can } \\
\text { be explained in many ways }\end{array}$ & $\begin{array}{l}\text { The world-view of those seeking to solve the problem } \\
\text { ends up being the determining factor in defining the } \\
\text { explanation of the causes of the problems and therefore } \\
\text { the solutions to be recommended. }\end{array}$ \\
\hline $\begin{array}{l}\text { There is no definitive formulation } \\
\text { of a problem }\end{array}$ & $\begin{array}{l}\text { The information needed to understand the problem } \\
\text { depends on the chances of solving this problem. The } \\
\text { understanding of the problem and its resolution are } \\
\text { concurrent. }\end{array}$ \\
\hline $\begin{array}{l}\text { There is no predefined set of } \\
\text { possible alternatives }\end{array}$ & $\begin{array}{l}\text { It is a matter of judgment set whether to continue to try } \\
\text { to increase the range of possible alternatives or whether } \\
\text { to work only with those already raised. }\end{array}$ \\
\hline Every problem is unique & $\begin{array}{l}\text { Each problem has its peculiarity, one aspect itself } \\
\text { or a combination of things that did not exist in other } \\
\text { problems faced in the past, making it difficult to } \\
\text { replication solutions. }\end{array}$ \\
\hline $\begin{array}{l}\text { The solutions are not true or } \\
\text { false, but good or bad }\end{array}$ & $\begin{array}{l}\text { There is no methodology or approach defined to deal } \\
\text { with these problems. }\end{array}$ \\
\hline You cannot operate through trial & $\begin{array}{l}\text { After implemented, he solutions can have effects which } \\
\text { propagate over time and space ways impossible to } \\
\text { trace }\end{array}$ \\
\hline
\end{tabular}

Table 2. Overview of characteristics of wicked problems. Sources: Rittel (1973), Nelson \& Stolterman (2003), Saboya (2012). Prepared by the authors.

While the classic mode of problem solving is basically reactive, strengthened and supported by well-developed solution procedures, in order to deal with wicked problems it is necessary to develop radically different strategies, given their complexity, ambiguity, and epistemological singularity.

The current demands require actors capable of handling complex problems, conceiving and implementing appropriate responses in real-life situations that are unique, contingent, unpredictable, and complex, as stand Nelson \& Stolterman (2003). Decision-making requires action and ability to act from a huge amount of incomplete information and constraints of resource and time, says Banerjee (2008). The author also argues that the Design approach, as an approximation of reality that intentionally embraces its vast richness and complexity, emerges as an alternative to purely rational and linear approaches. 
Indeed, a contemporary design culture able to "re-imagine the contours of society" (Utrecht Manifest, 2015) it is needed in order to support systemic change. In this sense, it is interesting to highlight Transition Design, as an area of design research, practice and study - as proposed by the School of Design at Carnegie Mellon University in $2012^{2}$. The concept is based on bringing together initiatives and discourses from academia, non-profit and community sectors (such as the Transition Town Network) that are often unrelated to each other or to the field of design. Therefore, this approach proposes "an understanding of the interconnectedness and inter-dependency of social, economic, political and natural systems" (Irwin et al., 2015, p. 1).

\subsection{Ways of Designing: Approaches and Methods}

The Design approach uses a process of composition that brings together a variety of elements, forming a functional whole that generate emergent creative qualities. The following analysis of the Design approach will be referred to the works of Banerjee (2008), Cardoso (2012), Cross (1982, 1999), Margolin (2015), Saikaly (2006), Friedman (2012), Krucken (2008), Moraes (2010) and Norman (2010).

As pointed out by Norman (2010), the field of Industrial Design was focused on physical products while currently the focus expanded to work in organizational structures and social problems, services, interaction and experience design. As a result, says the author, designers have become applied behavioral scientists.

a. Indeed, it is the integration of specific design knowledge with a larger range of understandings that enables designers to focus on problems in a rich, systemic way to achieve desired change -reinforces Friedman (2012). Considering the role of the designer regarding complex contemporary issues, Cross $(1982,1999)$ proposes the idea of 'designerly ways of knowing', signaling different possibilities for intervention, acting from the peculiar forms of knowledge and skills of designers:Designers tackle 'ill-defined' problems;

b. Their mode of problem-solving is 'solution-focused';

c. Their mode of thinking is 'constructive';

d. They use 'codes' that translate abstract requirements into concrete objects.

In other words, what makes Design a promising agent in contexts of change is a dynamic set of skills, cognitive processes and methodologies. The following are characteristics potentially presented by designers, seen as ideal conditions. The compilation was based in the works of Banerjee (2008), Owen (2005), and d.school (2010):

a. Applied and creative knowledge field: designers are proactive and inclined to action.

b. Human-centered focus: designers must continually consider how what is being created will respond to the human needs; focus on human values and empathy.

c. Combination of various cognitive processes: abductive thinking ('logic of the possible'), eduction (bringing hidden insights and latent opportunities) and retroductive thinking (allowing guessing under what conditions a given phenomenon can emerge). 
d. Iterative method of working: prototyping (highly effective alternate to pure analysis) as well suited methods to working on complex problems, allowing to develop concepts on multiple fronts in real context.

e. Synthesis and ability to visualize: designers conduct synthesis and produce a coherent vision out of messy problems. Creativity and skills to create and communicate novel visions of the future.

f. Radical Collaboration: designers are efficient in multi-disciplinary settings, catalyzing focus, nurturing a culture of creativity, shared vision and communication between different disciplines.

g. Systemic vision: the field integrates psychological, cognitive, technological, social and economic aspects to the ability to implement plans.

h. Affinity for team work: designers share their methods and have the ability to stimulate creativity and problem-solving capacity on people from other disciplines.

Design reveals its potential as a methodology for intervention demonstrating: (a) ability to consider holistic dimensions of problems; (b) capacity to manage complexity and tensions around innovation; (c) a natural propensity to act as a mediator; adds Moraes (2010). It is also observed that the characteristics of Design such as interpretative richness, ability to think systemically and envision futures and language inventiveness, can contribute to develop a plurality of solutions and foresee possible scenarios, as stated by Krucken (2008) and Cardoso (2012). Finally, an important reference regarding the approaches of Design Research to 'fuzzy problems' is the study “Approaches to Design Research" developed by Saikaly (2005). The author investigated several design projects and identified that they can constitute an integral part of research processes, being "used to capture, analyze, explore and transmit ideas through sensibility, invention, validation and implementation" (Saikaly, 2005).

Studies show that using perspectives and skills from the Design field generates a broader and deeper understanding about processes of social change, supporting the advancement of research and strategies oriented to support social innovation ${ }^{3}$. The following discussion section explores Design processes focusing on social change and supporting the transition to sustainability.

\section{Teaching Design for Transition}

In the classical thinking traditions, change is seen as a consequence of chance or necessity. Focusing on problems as the primary motivator to take action has limited our ability to position change as a result of intent and purpose, as reinforce Nelson \& Stolterman (2003). The authors stated that by changing the thinking focus, a change motivated by Design can be proactive and intentional, creating conditions for concrete expression of intent and human potential, in a consciously designed process (designed evolution).

Irwin (2015) highlights the centrality of theories of change for the design activity and remind us that the transition to sustainable systems will require a radical change at every level of society. In the Transition Design framework, designers must remain open to 
change even their own theories of change: those are configured as a "continually co-evolving body of knowledge that challenge designers to become lifelong learners who look outside the disciplines of design for new knowledge" (Irwin, 2015, p. 234). These aspects are fundamentally important to rethink design education.

The present study approaches Design processes focusing on social change and supporting the transition to sustainability, for which it offers a range of potentialities and interfaces for action, being able to support and propose creative paths for innovative practices. Design can be a powerful catalyst for sustainability and social innovation, as an effective methodology of intervention, proposing plural solutions and new scenarios, establishing conditions for the creative context, developing tools and infrastructure to support promising practices, and facilitating convergence towards shared ideas and potential solutions (Krucken, 2008; Landry, 2000, Malaguti, 2009; Manzini, 2008).

Since the integration of Design Thinking and practices in initiatives for social change and sustainability will necessarily involve socio-cultural innovations, this study proposes a reflection mainly about: (a) specific Design approaches, methods and tools for projects aiming for social change; (b) results and impacts of the application of Design for social change in short and long term.

Following are presented three initiatives teaching design for transition, showing an increasing expansion and recognition of Design values and praxis focusing social change and sustainability. The initiatives concern: (a) By design or by Disaster, a practice-oriented conference developed at the International University of Bolzan in Italy, b) Create! Ideation for Innovation, which promotes the co-design processes in an interdisciplinary innovation undergraduate course in USA (c) Laboratory of Design, Co-creation and Sustainability, that focus on design strategies to promote the culture of sustainability among youth in Brazil. These cases were chosen in order to show trends in Design teaching and research, in situations where the problems are complex, wicked, and require innovative solution methods.

\section{Initiative 1: By design or by disaster - an initiative in Italy}

By design or by disaster 4 is a practice-oriented conference that aims at showing, discussing and experimenting different possibilities of design and developments towards a more sustainable world. This annual event is hold by the Faculty of Design and Arts, Free University of Bozen/Bolzano and aims at bringing together professionals and students to discuss Design as a catalyst of change and co-design concrete practices and visions for tomorrow. The event is part of the Master Eco-Social Design, which is a 2-year practice-oriented and transdisciplinary study course 5 . The students are actively joining the organization of this annual event, under the coordination of Prof. Kris Krois since 2015.

The central idea of this practice-oriented initiative is that design "can contribute fundamentally to the development towards a sustainable world by considering patterns of production, consumption, disposal, communication and social interaction", whether in sustainable or unsustainable ways. The idea of "by design or by distaster" reinforces exactly this point: that conscious design can indeed foster resilient and equitable eco-socioeconomic systems (avoiding disaster, or avoiding the creation of unsustainable patterns). One of the purpose of this conference is to offer a practical situation in which a problem 
is shared, and the participants are invited to propose and develop together ideas, concepts and solutions in specific social and environmental contexts. In 2016 the focus of the workshop was to join the initiative Brave New Alps ${ }^{6}$ at Rovereto, Italy, that is engaged with the politics of care and the ethics of community economies. The participants were invited to visit the QuerciaLAB, a community economies research and resource centre that is hosted in a disused industrial space $\left(200 \mathrm{~m}^{2}\right)$, which is part of a complex of buildings that have been re-functioned in 2015 in order to host up to 80 asylum seekers. The Centre is conceived as a multifunctional space that will grow into an interface that through 'making', research and culture fosters the creation of alternative socio-economic relations between old and new inhabitants of the Vallagarina district and beyond, as describes Brave New Alpes. Together with the asylum seekers, participants developed a joint solution for signalization and identification of the space, aiming at reinforcing the feeling of belonging to the community (See Figure $1 \mathrm{a}$ and $1 \mathrm{~b}$ ).

It is also important to observe how this conference and workshop are connected to the region and the challenges that local communities have been facing. The South-Tyrolean area of Upper Vinschgau is undergoing drastic changes in agricultural practices as industrialised apple cultivation is making its way up the valley and this is part of the challenge that farmers and inhabitants face. This change affects the local economy, the environment, the quality of life and cultural practices, as consequences of monocultures on the ecosystem as well as on the homogenisation of the landscape. In the edition of 2017, the aim of the workshop, as stated by the conference coordinators, is to engage with these questions and to develop concrete design proposals that could contribute to sustainable developments in the area.

\section{Initiative 2: Course Create! Ideation for Innovation - an initiative in USA}

The second case consists in the use of co-design activities as a way to foster reflection, ownership and innovative mindsets in creative practice for change among undergraduate students at Virginia Tech, United States. As described by Mouchrek, Baum and McNair (2016), the initiative was developed within Create! Ideation for Innovation, a cross-college undergraduate course aimed at open ideation and creative inquiry (including student groups that include engineering, science, design, and humanities majors). One of the goals of the course was to improve creative practice seeking to incorporate strategies to address uncertainty by immersing students in a Design Thinking environment.

Students were involved in a semester-long design project, based on open innovation for social change. The problem framing and initial motivations for the projects came from students' own motivations. Among the teaching strategies used throughout the course, there was a co-creation activity (See Figure 2) that led students to collectively discuss and construct comprehensive diagrams about innovation as a way to reflect about their own projects, theories of change and frameworks for innovative practice. As a teaching tool configuring a participatory mode of innovation and research, the activity was designed to encourage the development of competencies that are critical to a design mindset and managing uncertainty avoidance (Mouchrek, Baum \& McNair, 2016). 


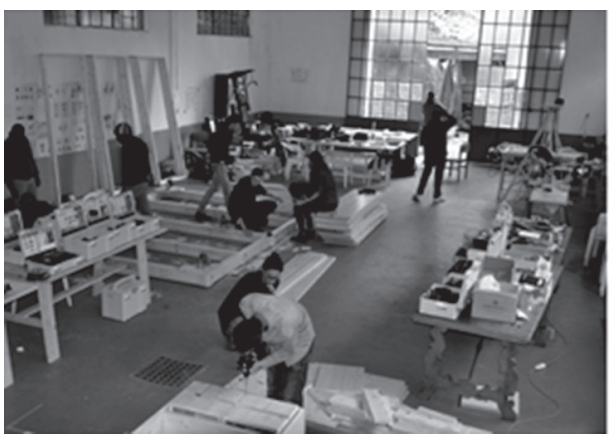

Figure 1a.

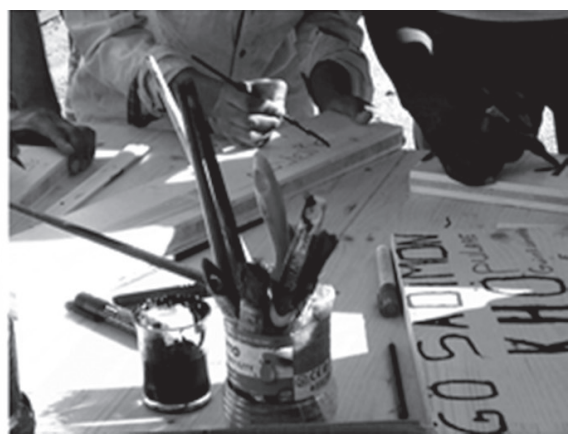

Figure 1b.

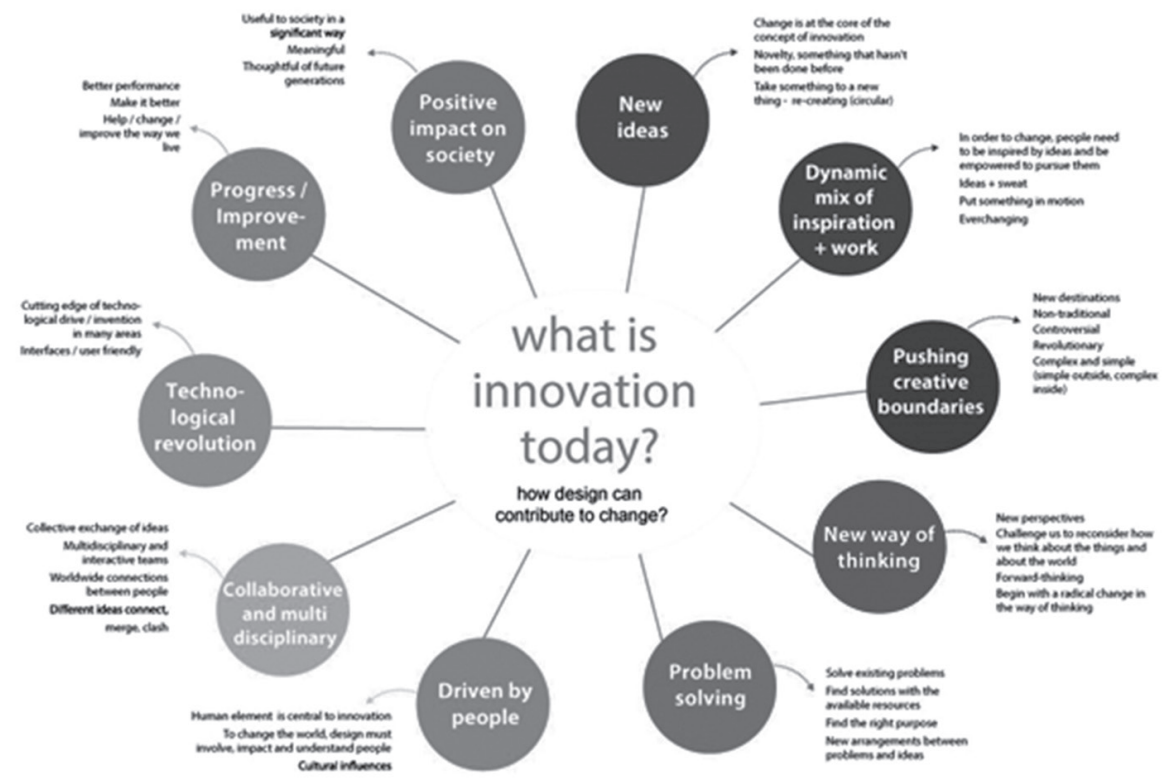

Figure 2.

Figure 1a. Quercialab. Photo: Brave New Alpes, 2016. Figure 1b. Workshop at Quercialab. Photo: Krucken, 2016. Figure 2. Collective map develop within the Co-creation activity in the course Create! Ideation for Innovation. Source: Mouchrek, Baum \& McNair (2016). 
The co-creation activity promoted students' collaboration, collective thinking and shared vision, communication, ability to make changes in their perspectives of current works, and reflection about their own visions about change. Students were able to connect the results of the activity with a critical review of their semester-long project.

Initiative 3: Laboratory of Design, Co-creation and Sustainability an initiative in Brazil The Laboratory of Design, Co-creation and Sustainability (Figure 3a and 3b) was developed as an undergraduate course for Design students, elaborated and conducted by the authors at the State University of Minas Gerais (Brazil), in 2013. It was conceived as a Design School Lab, defined as "a team of researchers, teachers and students who orient their didactic and research activities towards promoting sustainable changes" (Manzini, 2011), aiming to constitute a formative design research environment (Binder et al, 2011). The primary objective of the Laboratory was to promote experimentation of strategies of co-creation and sustainability tools, teaching students to identify and apply different possibilities to develop a Design project. Following an experimental approach, the course aimed to extend the capability of active intervention of future designers in contexts of transition towards sustainability, encouraging them to interact collaboratively to develop, facilitate and implement innovative solutions in this field.

The students were asked to develop an open project, in two phases: 1) Applied research; 2) Project development. The design focus was defined as promoting the culture of sustainability targeting young audience from 14 to 24 years old. The results of co-creation processes include: a) the development of microcredit funds that can support the solution of issues of collective interest of the students themselves, and b) the development of a communication platform for identification, discussion and collective solutions to common issues among young people in particular contexts. In both kinds of solutions, the central role of communication strategies could be noticed. It is also observed that all projects aimed to generate common good, with real social impact for the concerned communities.

\section{Thoughts about Design education aimed to promote social change}

In this section we propose a brief analyses of the three initiatives presented. It is possible to identify many elements that are characteristic of a "design for transition" approach, as described in the previous sections in this paper, but we would like to focus on two of them: a) Design approaches, methods and tools for projects aiming for social change; and b) results and impacts of the application of Design for social change in short and long term.

\footnotetext{
a. Specific Design approaches, methods and tools for projects aiming for social change In the Initiative 1, methods include practical case study and exchange of experiences, as well participatory activities, as part of the practice-oriented conference. Students were invited to join all the activities, since planning and organizing the event it self, as well the workshops, using methods and tools of design. This approach fosters a strong community
} 

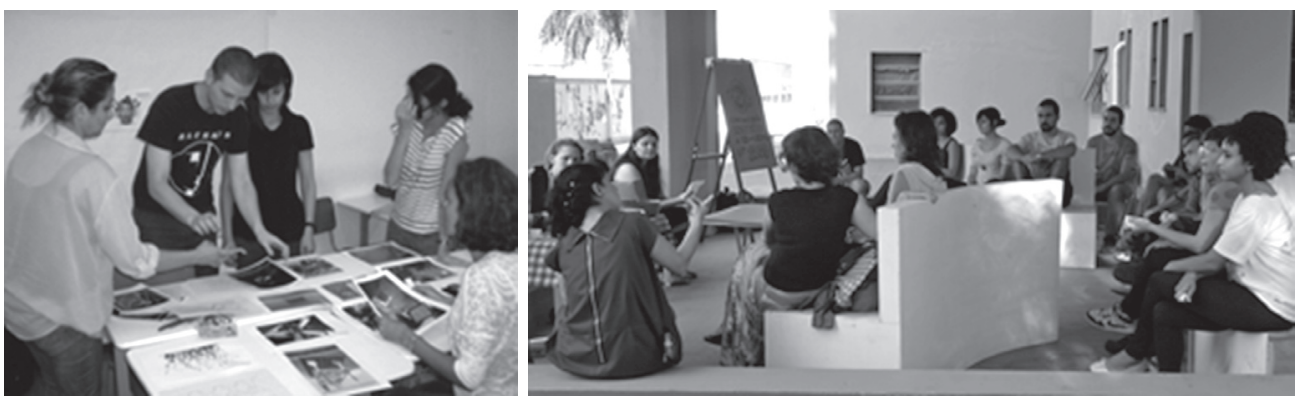

Figure 3a and 3b. Laboratory of Design, Co-creation and Sustainability. Source: Mouchrek \& Krucken (2014).

feeling and engages students and other participants to share responsibility for the results of the discussion and actions developed. In this sense, the initiative offers as concrete opportunity for immersion in a specific context, understanding sociocultural aspects and figuring out the role (and responsibility) of design in promoting change. By interacting and reflecting on the praxis, this experience promotes a "learning by doing together" approach. In the Initiative 2, the method was centered in participatory co-creation activities, which addressed many levels of creativity (inspiration, appropriation, making, and productivity), with special highlight to their potential to enhance processes of appropriation, strengthening students' understanding of the context and their ability to influence it. In the forementioned course, students "creatively appropriated the concept and the landscape of innovation; while making it their own, they became able to critique and change their own approaches to the projects" (Mouchrek, Baum \& McNair, 2016, p. 13). Another promising feature for teaching design for transition it the fact that co-creation activities provide opportunities for experimentation in which students can explore the possibility of creating solutions their own resources and motivations for action, while creating possibilities of developing concrete and action-oriented projects. Students' ownership of the process also stimulates a process of continuous change in the scope and orientation of the project.

Similar methods were successfully explored in the Laboratory of Design, Co-creation and Sustainability, the third initiative, several competences were involved and stimulated. Design Tools such as visual mapping, collaborative maps, ideation sessions, desktop research, visualization techniques, questionnaires and surveys, virtual prototyping and immersion with user participation were applied. These tools and schemes for structuring, synthesis and presentation of project aimed to direct the concept definition and the development of the project, assuring consistency while maintaining the flexibility and room for innovation. 


\section{b. Results and impacts of the application of Design for social change in short and long term}

"Learning by doing together", as the first initiative stresses, can have positive impacts and results as a pedagogic as well as an interventional approach. The process of participatory design applied to societal issues, within a community context, can foster the development of participant's competencies and skills, diffusing Design Thinking. This result stays with people and can support the community to face changes and create solutions for the territory. The repeated happening of "design events" (as this kind of intervention) can help to promote local innovation dynamics, bringing together actors that can work together towards more sustainable alternatives and systems.

The second initiative showed potential to transform students' mindsets about social change and the application of design in transition settings. The projects proposed ranged from innovative strategies for visitation in national parks in U.S. as a way to promote sustainability awareness to the reorganization of campus facilities for improve students' well-being, collective study and community cohesion.

The third one, Laboratory of Design, Co-creation and Sustainability, promoted interesting results and proved to be a promising initiative to promote design-based engagement in sustainability and social change, insofar as it resulted in the production of concrete collective results, from the joint dynamics of diverse expertise and perspectives. The open approach led to the development of competencies such as: context analysis, proposal of foci for intervention, research and selection of information and forms of intervention, knowledge and selection of Design Tools, synthesis, visualization, familiarity with development and design stages and ability of organization and communication.

All the three alternatives are relevant opportunity to learn and practice skills that students usually don't do within the academic contexts. As example, the ability to interact with heterogeneous groups, which is essential in mediating and integrating different universes and understanding of plural cultural contexts in the design of products and services. Learning to interact is also a crucial aspect for the development and implementation of collaborative solutions. As states Margolin (2005), the international community of design educators and designers can recognize its own power as a collective agent of change, rethinking ways of living and community, and "translating into propositions for projects that inspire people to carry them out".

\section{Final Considerations}

Reflections on the concept and nature of Design, its foundations and paths are important for the development of this field of study and intervention in a complex and multifaceted world. For this, it is necessary to develop a conscious practice of Design, as a result of reflective practice, intellectual perception and intentional choice, at the same time open and critical. The authors cited in this text seem to converge on this need.

The initiatives aforementioned corroborate the idea of empathy being a key to the process as a whole. From the principle of "attitudinal design", the designer's approach during the project has larger influence on the final result. Designers must adopt a decisive posture 
in a way that maintains the distance needed to get an accurate perspective on the issue to resolve or develop. Otherwise, professionals that usually get too involved with the project, end up losing the necessary critical perspective to evaluate the solutions proposed.

Furthermore, this aspect emphasizes the responsibility of the educators in the formation of designers able to face contemporary challenges, using their potential as an alternative mode of intervention in complex social issues, meanwhile capable of self-management during the process. Although, the development of a method of self-control for designers seems yet underexplored, it is extremely important to create a new sphere of influence, integrating activities and research, design practice and reflection, in order to allow an enabling environment to systemic and creative solutions.

In conclusion, we can point out four essential aspects for further enquiry and reflection. The first one regards the need to develop a critical vision in Design research and teaching. Awareness and criticism of own references and actions is crucial to the performance of Design at a systemic level, for the development of identity and local culture. Innovative approaches are addressing the need to develop reflective and critical thinking in the Design education ${ }^{7}$. The second aspect -that is closely connected to the first one; refers to the need to identify the values embedded in the design praxis: What does define Design "good practices"? What are references for successful design projects, considering their impact in the society and its welfare? Research and reflection about values in the transition towards a more just and sustainable society are essential in the context of social change.

The need to systematize and teach specific design methods and tools for social change constitute the third aspect. As we can note with the discussion that this paper proposes, there are many opportunities and challenges for designers. Design methods that support the development of autonomy, entrepreneurship and community base empowerment are crucial, and especially more needed in dynamic contexts where a multitude of problems (and solutions and opportunities) are frequently emerging.

Finally, designers and researchers in this context are invited to: (a) invest in a deeper understanding of Design in times of transition; (b) work to develop, articulate and communicate knowledge in Design; (c) nourish a context for recognition and development of the Design tradition; (d) rethink Design culture and forms of intervention in society, especially in emerging contexts; (e) act as a catalyst in the formation of environments for social creation and transformation.

\section{End Notes}

1. Elements from Sections 1 and 2 are part of an in progress doctoral research.

2. http://transitiondesign.net

3. See one example addressing Design strategies for social change regarding youth people in Mouchrek, N. M. (2014). Design strategies and competences to promote the culture of sustainability among youth. State University of Minas Gerais, Brazil..

4. http://designdisaster.unibz.it

5. https://www.unibz.it/en/faculties/design-art/master-eco-social-design/

6. http://www.brave-new-alps.com 
7. For examples see the discussion previously presented by the authors.

8. For more information about skills of design in the contemporary society see the works of Manzini (2015), Thackara (2005), Del Gaudio et al. (2014), and Krucken (2008), among others.

\section{References}

Archer, B. (1979).'The three Rs' Design Studies. v. 1, n.1.

Banerjee, B. (2008). Designer as Agent of Change. A Vision for Catalyzing Rapid Change. Changing the Change Conference, Torino.

Cardoso, R. (2012). Design para um mundo complexo. São Paulo: Cosac Naify.

Cross, N. (1982). Designerly ways of knowing. Design Studies, London, v. 3, n. 4, p. 221-227.

Cross, N. (1999). Design Research: A Disciplined Conversation, Design Issues, v.15, n. 2.

Del Gaudio, C.; Oliveira, A. J. de; Franzato, C. (2014); “O Tempo no Design Participativo", p. 957-969 . In: Anais do $11^{\circ}$ Congresso Brasileiro de Pesquisa e Desenvolvimento em Design [= Blucher Design Proceedings, v. 1, n. 4]. São Paulo: Blucher, 2014. DOI 10.5151/ designpro-ped-00372

Friedman, K. (2000). Creating design knowledge: from research into practice. In: IDATER 2000 CONFERENCE, 2000, Proceedings. Loughborough: Loughborough University.

Friedman, K. (2012). Models of Design: Envisioning a Future Design Education. Visible Language 46.1/2.Available at: https://www.academia.edu/2508775/Friedman._2012._ Models_of_Design. Accessed on 07/14/2016.

Irwin, T. (2015). Transition Design: A Proposal for a New Area of Design Practice, Study, and Research. Design and Culture, 7(2), 229-246.

Irwin, T.; Kossoff, G.; Tonkinwise, C.; Scupelli, P. (2015) Transition Design: An Educational Framework for Advancing the Study and Design of Sustainable Transitions, 6th International Sustainability Transitions Conf., University of Sussex, UK. Available at: http:// design.cmu.edu/sites/default/files/Transition_Design_Monograph_final.pdf. Accessed on $10 / 08 / 2017$.

Krucken, L. (2008) Skills for design in contemporary society. In: Moraes, D.; Krucken, L. (ed.) Design and tranversality Belo Horizonte: Santa Clara. Available at: https://www.academia. edu/12809560/Skills_for_design_in_contemporary_society. Accessed on 07/14/2016.

Krucken, L.; Mol, I. (2014). Abordagens para cocriação no ensino de design: reflexões sobre iniciativas no contexto da graduação e da pós graduação, p. 992-1000. In: Anais do $11^{\circ}$ Congresso Brasileiro de Pesquisa e Desenvolvimento em Design [Blucher Design Proceedings, v. 1, n. 4]. São Paulo: Blucher, DOI 10.5151/designpro-ped-01062

Landry, C. (2000). The Creative city. A toolkit for Urban Innovators. Earthscan Publications LTD, London UK.

Malaguti, C. (2009). Design e valores materializados - cultura, ética e sustentabilidade. In: Cadernos de Estudos Avançados em Design Sustentabilidade I. 1 ed. Barbacena: EdUEMG, v.1.

Manzini, E. (2008). Design para a inovação social e sustentabilidade: comunidades criativas organizações colaborativas e novas redes projetuais. Rio de Janeiro: Cadernos do Grupo de Altos Estudos, v. 1. 
Manzini, E. (2015). Design, when everybody designs: an introduction to design for social innovation. London: The MIT Press.

Margolin, V. (2015). Social design: From utopia to the good society. In M. Bruinsma \& I. van Zijl (Eds). Design for the good society (pp. 28-42). Utrecht, the Netherlands: Stichting Utrecht Biennale.

Moraes, D. (2010). Metaprojeto: o design do design. 1. ed. São Paulo: Blücher, v. 1.

Mouchrek, N. M. (2014). Design strategies and competences to promote the culture of sustainability among youth. State University of Minas Gerais, Brazil.

Mouchrek, N., Baum, L., \& McNair, L. D. (2016). Student Persistence Through Uncertainty Toward Successful Creative Practice. In American Society for Engineering Education Annual Conference.

Mouchrek, N.; Krucken, L. (2014). Laboratório de design, cocriação e sustentabilidade: uma iniciativa no ensino de design. p. 1654-1666. In: Anais do $11^{\circ}$ Congresso Brasileiro de Pesquisa e Desenvolvimento em Design [Blucher Design Proceedings, v. 1, n. 4]. São Paulo: Blucher, DOI 10.5151/designpro-ped-01234

Mouchrek, N. (2015). Design for Youth Empowerment. PhD project, Unpublished document.

Nelson, H.G. and Stolterman, E. (2003). The Design Way: intentional change in an unpredictable world. Educational Technology Publications, Englewood Cliffs, NJ.

Norman, D. (2010). Why Design Education Must Change. Core77, 2010 November 26, 2010. Available at: http://www.core77.com/posts/17993/why-design-education-mustchange-17993. Accessed on: 07/14/2016.

Owen, C. L. (2005). Design Thinking. What It Is. Why It Is Different. Where It Has New Value. Life and Design in the Future Conference, Keynote address. South Korea.

Rittel, H., Webber, M. (1973). Dilemmas in a General Theory of Planning. Policy Sciences 4, 2. Saboya, R. Problemas "capciosos". Available at: http://www.urbanidades.arq.br. Accessed on: $12 / 14 / 2012$.

Saikaly, F. (2005). Approaches to design research: towards the designerly way. In: The 6 th International Conference of the European Academy of Design, Design System Evolution. The University of the Arts Bremen, Germany, 29-31 March 2005. Available at: http://www. verhaag.net/ead06/fullpapers/ead06_id187_2.pdf. Accessed on: 01/20/2016.

Thackara, J. In the bubble: designing in a complex world. Cambridge: MIT, 2005.

Utrecht Manifest. Available at http://www.utrechtmanifest.nl. Accessed on 09/25/2016.

Resumen: El artículo analiza el papel del Diseño como agente de transformación social frente a desafíos complejos. Abrazar intencionalmente la complejidad de la realidad y centrarse en los valores humanos, el enfoque de Diseño es adecuado para desarrollar perspectivas alternativas y estrategias de cambio radicalmente diferentes. El documento explora la enseñanza de Diseño centrándose en el cambio social y la transición a la sostenibilidad, presentando tres iniciativas y reflexionando sobre los métodos y los impactos de la aplicación del Diseño para la transición. El análisis señala la necesidad de una visión crítica en la investigación y enseñanza del diseño y la importancia de sistematizar y enseñar métodos y herramientas para apoyar la interacción entre los diversos actores sociales. 
Palabras clave: Cultura de diseño - Diseño para el cambio - Cambio social - Transición a la sostenibilidad - Activismo de diseño - Complejidad - Problemas perversos (wicked problems).

Resumo: $\mathrm{O}$ artigo analisa o papel do Design como agente de transformação social diante de desafios complexos. Adotando intencionalmente a complexidade da realidade e focalizando os valores humanos, a abordagem do Projeto é adequada para desenvolver perspectivas alternativas e estratégias de mudança radicalmente diferentes. O documento explora os ensinamentos do Design com foco na mudança social e a transição para a sustentabilidade, apresentando três iniciativas e refletindo sobre os métodos e impactos da aplicação do Design para a transição. A análise faz foco na necessidade de uma visão crítica na pesquisa e ensino do design e na importância de sistematizar e ensinar métodos e ferramentas para apoiar a interação entre os diferentes atores sociais.

Palavras chave: cultura de design - design para a mudança - mudança social - transição a sustentabilidade - ativismo de design - complexidade - problemas perversos (wicked problems) 